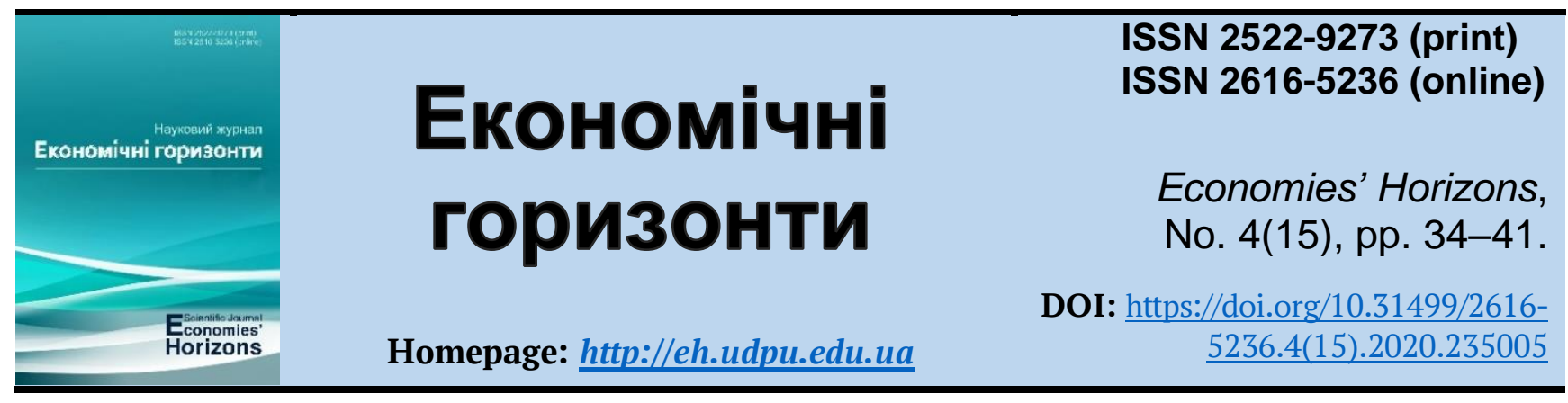

UDC $65.012 .8+338.24$

\title{
Organization of scientific research in the system of financial and economic security: Essence, tasks and methodological approaches
}

\author{
Lida P. Rogatina ${ }^{1}$, Doct. Ec. Sc., Associate Professor
}

Received: 21 October 2020 Accepted: 4 December 2020
Rogatina, L. P. (2020), "Organization of scientific research in the system of financial and economic security: essence, tasks and methodological approaches", Economies' Horizons, no. 4(15), pp. 34-41, doi: https://doi.org/10.31499/2616-5236.4(15).2020.235005

Abstract. The purpose of the article is the study of the essence, objectives and methodological approaches to the organization of scientific research in the system of financial and economic security. Methodology. The scientific works of scientists in the organization of scientific research of financial and economic security are the theoretical and methodological basis of the study. In order to achieve the established goal of the article, the following research methods were used: theoretical generalization the essence, the system of indicators for assessing financial and economic security; methods of positive and normative analysis - for the development of recommendations for improving the organization of research in the system of financial and economic security. Results. The essence of the definition of financial and economic security system has been investigated. The absence of a singular approach to defining the essence of the concept of financial and economic security among domestic scientists has been determined. The difference in approaches of domestic scientists to the financial and economic security have been proven. The following approaches to understanding the essence of the concept of economic security of the enterprise have been outlined as protection against: unauthorized access to information; methods of unlawful competition, threats. Also, the economic security of the enterprise is distinguished as a state of stability or equilibrium or efficient use of its resources. Some define economic security as dependent on the harmonization of interests. A system of indicators characterizing the state of financial and economic security and meeting such requirements is presented: are easy to calculate and understand; substantial and meaningful; based on current accounting and statistical reporting; operational for appropriate response to the state of financial security; characterize the qualitative and quantitative state in statics and dynamics. In the process of conducting scientific and economic research is described as task-solving. The mechanism of economic security management is revealed. Among the main methods of assessing the system of financial and economic security the following are determined: peer review, regression and analysis of variance, regression method and the method of exponential smoothing methods fuzzy systems, cluster and discriminant analysis. Systematization of methodological approaches to the organization of scientific research in the system of financial and economic security has shown that they are defined in terms of resource (investment) system, infrastructure (cluster) and process approaches. Practical significance. The research of essence, tasks and methodical approaches of the organization of scientific researches in the system of financial and

\footnotetext{
${ }^{1}$ Odessa National Academy of Food Technologies; Head of the Department of Economic Theory and Financial and Economic Security; ORCID ID: https://orcid.org/0000-0002-1055-810X; e-mail: rogatina.lida@gmail.com.
} 
Rogatina L. P. Organization of scientific research in the system of financial and economic security: Essence, tasks and methodological approaches

economic safety which can be used by applicants and scientists and pedagogical workers of higher education is resulted. Prospects for further research. Formation of the organization of scientific research in systems of financial and economic safety.

Keywords: methodical approaches, methods, financial and economic security, essence.

JEL Classification: B00, B41, B49, E00, J18.

Number of references: 12; number of tables: 1; number of figures: 2; number of formulas: $\mathbf{0 .}$

\title{
Організація наукових досліджень в системі фінансово-економічної безпеки: сутність, завдання та методичні підходи
}

\author{
Ліда Петрівна Рогатіна ${ }^{1}$, д. е. н., доцент
}

Стаття надіŭшла: 21.10.2020 Стаття прийнята: 04.12.2020
Rogatina L. P. Organization of scientific research in the system of financial and economic security: Essence, tasks and methodological approaches. Економічні горизонти. 2020. № 4(15). C. 34-41. DOI: $10.31499 / 2616-5236.4(15) .2020 .235005$

Анотація. Метою статті $\epsilon$ дослідження сутності, завдань та методичних підходів організація наукових досліджень в системі фінансово-економічної безпеки. Методологія. Теоретичною і методологічною основою дослідження $є$ наукові праці вчених в організації наукових досліджень системи фінансово-економічної безпеки. Для досягнення поставленої в роботі мети були використані такі методи дослідження: теоретичне узагальнення - сутності, системи показників оцінювання фінансово-економічної безпеки; методи позитивного і нормативного аналізу - для вироблення рекомендацій щодо удосконалення організації наукових досліджень в системі фінансово-економічної безпеки. Результати. Досліджено сутність визначення поняття «система фінансово-економічна безпека». Визначено, що єдиного підходу до визначення сутності поняття «фінансово-економічна безпека» серед вітчизняних науковців відсутнє. Доведено, що вітчизняні науковці фінансово-економічну безпеку розрізняють з різних підходів. Виділяють наступні підходи до розуміння сутності поняття економічної безпеки підприємства як захист від: несанкціонованого доступу до інформації; методів кримінальної конкуренції, загроз. Також, економічну безпека підприємства розрізняють як стан стійкості чи рівноваги або ефективного використання його ресурсів. Деякі визначають, що економічна безпека $\epsilon$ залежністю від гармонізації інтересів. Наведено систему показників, що характеризують стан фінансовоекономічної безпеки та відповідають таким вимогам: $є$ простими для розрахунку і для розуміння; суттєвими і значущими; базуються на чинній бухгалтерській та статистичній звітності; оперативними для відповідного реагування на стан фінансової безпеки; характеризують якісний та кількісний стан у статиці і динаміці. Охарактеризовано, що у процесі проведення науковоекономічних досліджень, вирішуються завдання. Розкрито механізм управління економічною безпекою. Визначено, що серед основних методів оцінювання системи фінансово-економічної безпеки визначають: експертних оцінок, регресійного і дисперсійного аналізу, регресійний метод і метод експоненціального згладжування, методи дослідження нечітких систем, кластерний та дискримінантний аналіз. Систематизація методичних підходів до організації наукових досліджень в системі фінансово-економічної безпеки показала, що їх визначають 3 точки зору ресурсного (інвестиційного) системного, інфраструктурного (кластерного) та процесного підходів. Практичне значення. Наведено дослідження сутності, завдань та методичних підходів організація наукових досліджень в системі фінансово-економічної безпеки, що можуть бути використанні здобувачами та науково-педагогічними працівниками вищої освіти. Перспективи

\footnotetext{
1 Одеська національна академія харчових технологій; завідувач кафедри економічної теорії та фінансово-економічної безпеки; ідентифікатор ORCID: https://orcid.org/0000-0002-1055-810X; e-mail: rogatina.lida@gmail.com.
} 
подальщих досліджень. Формування організації наукових досліджень в системи фінансовоекономічної безпеки.

Ключові слова: методичні підходи, методи, фінансово-економічна безпека, сутність

Кількість джерел: 12; кількість таблиць: 1; кількість рисунків: 2; кількість формул: 0.

\section{Introduction.}

The formation of scientific research in the system of financial and economic security is based on the influence of various factors, the greatest influence is exerted by macro-, meso-, micro- factors. Under such difficult conditions, scientific research in the system of financial and economic security is given a lot of attention by domestic scientists. However, constant changes encourage the formation of new approaches to the organization of research in the system of financial and economic security. Therefore, the study of the nature, objectives and methodological approaches to the organization of research in the system of financial and economic security is quite relevant.

\section{Literature review.}

The scientific works of modern economists are devoted to the problems of formation of the theory and methodology of financial and economic security of economic entities, the state security system, security techniques and technologies, in particular: I. Zhurba (2018), I. Irtyshcheva and I. Kramarenko (2011), A. Verhun and K. Strizhko (2018), O. Khomiv (2011), H. Akimova, O. Toporkova and T. Yevlash (2017), R. Varicheva (2016), N. Babina (2016), L. Ogarok (2016), I. Kramarenko and L. Kozachenko (2018), P. Kolisnichenko (2017), P. Putseteilo and O. Gumenyuk (2017) and others. However, the complexity and versatility of this study requires the formation of the organization of research in the system of financial and economic security.

\section{Methodology.}

The scientific works of scientists in the organization of scientific research of financial and economic security are theoretical and methodological basis of the study. In order to achieve the established goal of the article, the following research methods were used: theoretical generalization - the essence, the system of indicators for assessing financial and economic security; methods of positive and normative analysis - for the development of recommendations for improving the organization of research in the system of financial and economic security.

\section{Research objectives.}

The purpose of the article is the study of the essence, objectives and methodological approaches to the organization of scientific research in the system of financial and economic security.

\section{Results and discussions.}

In modern conditions, the science of economic security of the enterprise is a set of scientific knowledge that combines different concepts of economic security, its categorical apparatus and research methodology. Despite this, the conceptual and categorical apparatus of economic security of the enterprise is unsatisfactory, and its content is incomplete. Generalization of theoretical approaches to the essence of economic security of the enterprise allowed to explain its evolution and justify the need to move from semantic and static stages in understanding economic security (defined as the state of corporate security from threats or the most effective resource management) in a dynamic phase, which is defined by the effectiveness of the implementation of processes to ensure this state (Zhurba, 2018).

Domestic scientists distinguish between financial and economic security from different approaches (Figure 1). The following approaches to understanding the essence of the concept of economic security of the enterprise have been outlined as protection against: un- 
Rogatina L. P. Organization of scientific research in the system of financial and economic security: Essence, tasks and methodological approaches

authorized access to information; methods of unlawful competition, threats. The economic security of the enterprise is also distinguished as a state of stability or equilibrium or effi- cient use of its resources. Some define economic security as a dependence on the harmonization of interests.

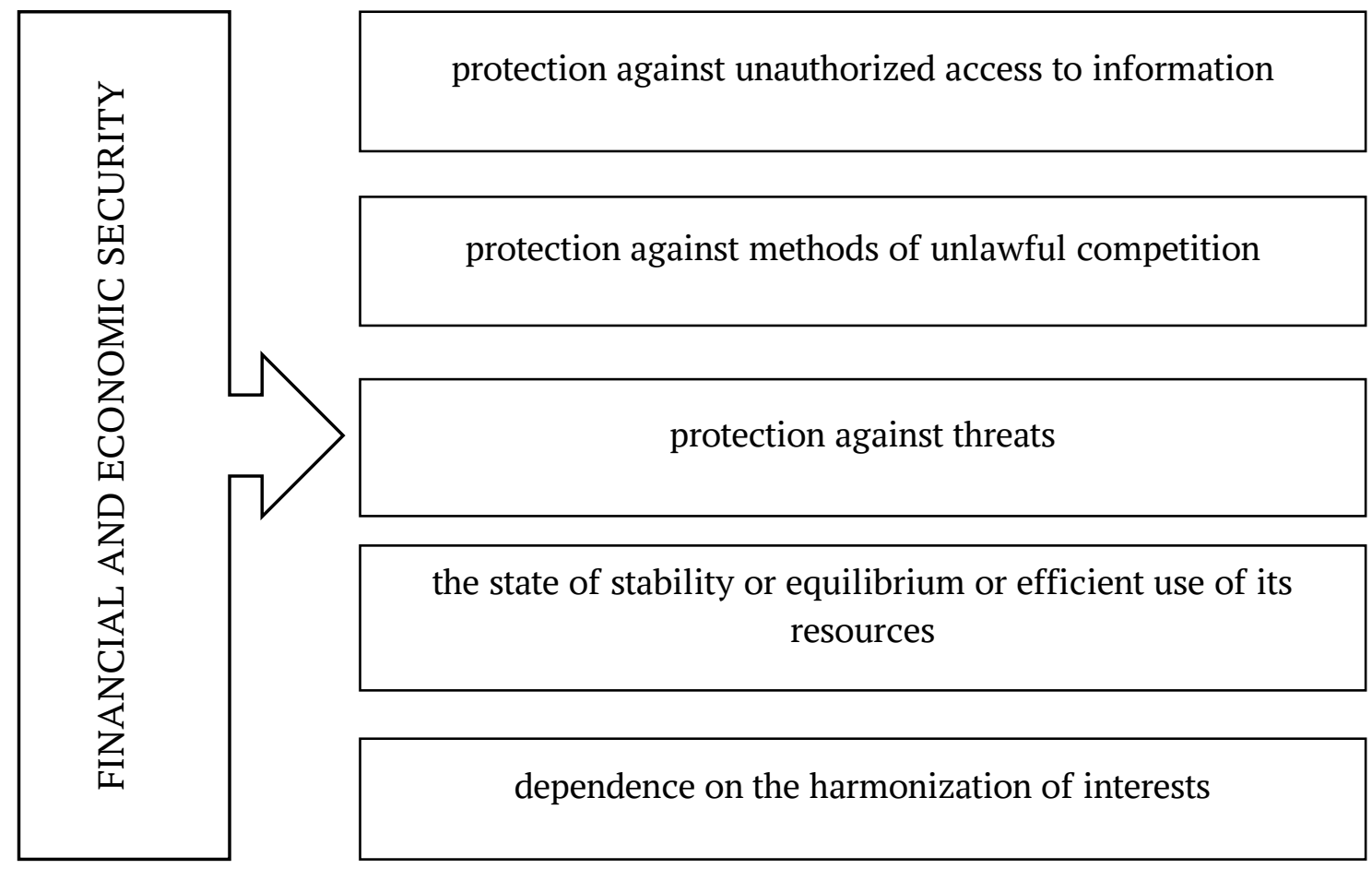

Fig. 1. Approaches to the definition of financial and economic security

Source: Formed by (Verhun, 2018).

Therefore, there is no single approach to defining the essence of the concept of financial and economic security among domestic scientists.

From the system of indicators that characterize the state of financial activity of the enterprise, one should choose those that following such requirements:

- are easy to calculate and understand. According to the indicator values through specially constructed mathematical formulas should range from 0 (no financial security) to 1 (the highest level of financial security);

- substantial and meaningful; based on current accounting and statistical reporting;

- operational for appropriate response to the state of financial security; characterize the qualitative and quantitative state in statics and dynamics;

- completely and comprehensively cover all aspects of the financial activities of the enterprise, adequately reflect the financial activities of the enterprise in the complex;

- characterize the sufficient depth and breadth of the retrospective of the state of financial security on the basis of constant monitoring;

- can be used in planning, accounting and analysis of financial activities of the enterprise.

Therefore, the system of indicators must characterize the state of financial and economic security and meet the following requirements: are simple to calculate and understand; substantial and meaningful; based on current accounting and statistical reporting; operational for appropriate response to the state of financial security; characterize the qualitative and quantitative state in statics and dynamics.

In the process of conducting scientific and economic research, as a rule, the follow- 
ing tasks are solved (Khomiv, 2011):

- description of socio-economic reality (study of the time budget, public opinion polls, activities, organization);

- explanation of contradictions or features of the functioning of social communities or processes (social conflicts, unemployment, staff turnover, tension in the workforce);

- predicting development trends (change in attitude to work, in the formation of social and labor relations, the dynamics of economic development);

- practical transformation of socioeconomic reality (introduction of social technologies, plans, projects).

In turn, the algorithm for building an economic security system should include the following stages:

- study of the specifics of the company's business, the market segment occupied by it, the staffing schedule, acquaintance with the company's staff;

- analysis of external and internal threats to the economy of the enterprise. $\mathrm{Ob}-$ taining information about crisis situations that arose earlier, the causes and their results;

- audit of existing (previously introduced) security measures and analysis of their compliance with identified threats;

- modeling of a new system of economic security of the enterprise;

- a plan to eliminate the comments identified during the audit;

- proposals for improving the system of economic security, calculation of all types of necessary additional resources;

- planned monthly expenses (budget) to ensure the functioning of the economic security system;

- approval by the head of the enterprise of the model of the new system of economic security and the budget for its support;

- direct construction of the economic security system of the enterprise;

- expert assessment of the effectiveness of the built system of economic security, bringing it to perfection (Akimova, Toporkova and Yevlash, 2018).

Systematization of types of methodological approaches to the assessment of economic security by quantitative parameters allowed to determine their strengths and weaknesses, and also is the basis for stakeholders to determine the appropriate methodology to obtain objective results of quantitative assessment. Taking into account the dependence of each of the methodological approaches to assessing the economic security of the enterprise from the peculiarities of accounting, the problems of theoretical and methodological nature in the field of accounting in the context of its compliance with the objectives of achieving economic security. The scientific significance and prospects of the study of these problems is substantiated by the need to form a theoretical and methodological basis for information management of economic security of the enterprise on the basis of accounting information (Varicheva, 2016).

The mechanism for managing the economic security of an enterprise operating in a crisis can be based on one of the following methodological approaches:

- the state of security is considered through protection against economic crimes and other encroachments (narrow meaning);

- the state of security is considered through protection from internal and external threats (the need to take into account which is not always realized by the management of the enterprise) and adaptive properties of the enterprise;

- the state of security is determined by the efficiency of use of resources or potential of the enterprise (resource-functional approach, which does not take into account the use of non-corporate resources to ensure the economic security of the enterprise and the dynamics of its development);

- security is perceived due to the presence of competitive advantages and economic potential (which without proper implementation does not guarantee the economic security of the enterprise); 
- security is considered as a degree of realization and protection of economic interests (developed interpretation with an emphasis on the creation of a specific system of protection of interests realized through functional components);

- a comprehensive approach to economic security management, which combines different methodological approaches (Babina, 2016).

Factors influencing the formation of the system of economic security of financial institutions in modern economic conditions are as follows: lack of financial resources of institutions and limited access to external sources of funding; dualism of the purpose of functioning of financial institutions; inexperience and insufficient level of knowledge of the staff of financial institutions; lack of quality documentary, informational and methodological support of the processes of formation and functioning of economic security systems of financial institutions; increasing pressure on professional financial market participants from state regulators; separation of owners of financial institutions from their direct management; reduction of the level of trust of individuals and legal entities in the institutions of the financial sector; lack of state programs to provide financial assistance to institutions; permanent increase in the number of threats to the activities of financial institutions; high level of fraud and other types of economic crime in the financial sectors; rapid development of information technology; the economic and political situation in the country, and the threats associated with it (Zachosova, 2016).

Evaluation methods are important in the organization of scientific research of the system of financial and economic security (Figure 2).

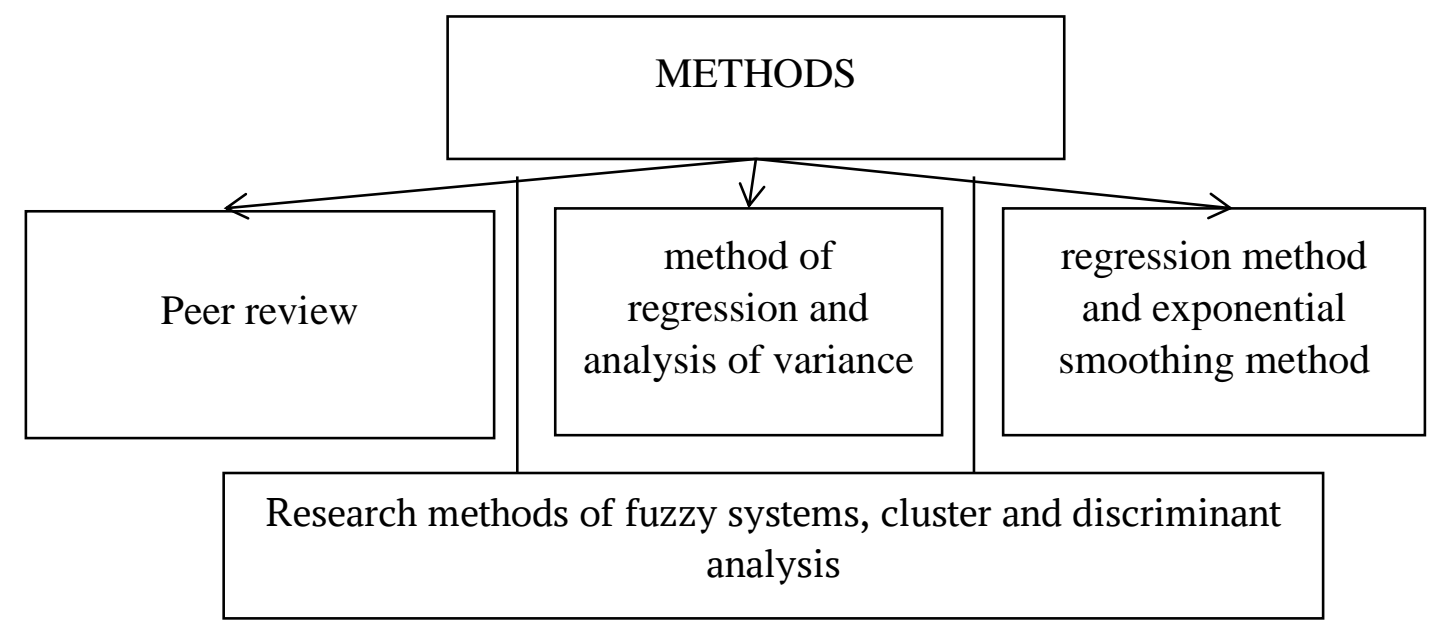

Fig. 2. Methods of assessing the system of financial and economic security Source: Compiled by author.

Among the main methods of assessing the system of financial and economic security are: expert assessments, regression and analysis of variance, regression method and method of exponential smoothing, methods of studying fuzzy systems, cluster and discriminant analysis.

Analysis of scientific papers on economic security of the enterprise and assessment of the level of this security, suggests that resource (investment) system, infrastruc- ture (cluster) and process approaches are leading in determining the main indicators of economic security of the entity (Table 1).

Market transformations at the present stage of formation of the economic system of Ukraine are accompanied by restructuring in the structure of financial resources of enterprises. At the same time, there is also a restructuring of the credit system in the form of expanding the range of credit relations, the emergence of new one's types of loans and 
credit instruments. Particular attention should be paid to lending to agri-food enterprises, which objectively require improvement of the credit climate. At the same time, the issues of improving methodological approaches to assessing the creditworthiness of agri-food enterprises remain relevant (Irtyshcheva and Kramarenko, 2011).

\section{Table 1. Systematization of methodological approaches to the organization of scientific research in the system of financial and economic security}

\begin{tabular}{|l|l|}
\hline \multicolumn{1}{|c|}{ Approach } & \multicolumn{1}{c|}{ Essence } \\
\hline Resource & $\begin{array}{l}\text { economic security of the enterprise is determined on the basis of the analysis } \\
\text { of sufficiency and availability of financial costs which are necessary for im- } \\
\text { plementation of production process, and also return on the invested resources } \\
\text { (Kolisnichenko, 2017). }\end{array}$ \\
\hline System & $\begin{array}{l}\text { in management involves a combination of functional and situational princi- } \\
\text { ples, combining the phases of management into a single management cycle } \\
\text { and different levels of objects and subjects of management into a single flexi- } \\
\text { ble organizational structure of economic security. Therefore, management of } \\
\text { economic security of the region should consider the possibility of changing } \\
\text { the language management system, ensuring its flexibility to respond to chang- } \\
\text { ing conditions by switching to alternatives (Ogarok, 2019). }\end{array}$ \\
\hline Infrastructural (cluster) & $\begin{array}{l}\text { provides cross-functional and inter-organizational coordination and integra- } \\
\text { tion of participants and partners of economic security systems. }\end{array}$ \\
\hline Processual & $\begin{array}{l}\text { economic security is ensured through the rational organization, management } \\
\text { and improvement of financial and economic processes occurring in the enter- } \\
\text { prise. (Pucenteilo and Humeniuk, 2017). }\end{array}$ \\
\hline
\end{tabular}

Source: Compiled by author.

The essence of the definition of the concept of financial and economic security system has been investigated. The absence of a singular approach to defining the essence of the concept of financial and economic security among domestic scientists has been determined. The difference in approaches of domestic scientists to the financial and economic security have been proven. The following approaches to understanding the essence of the concept of economic security of the enterprise have been outlined as protection against: unauthorized access to information; methods of unlawful competition, threats. Also, the economic security of the enterprise is distinguished as a state of stability or equilibrium or efficient use of its resources. Some define economic security as dependent on the harmonization of interests.

\section{Conclusions.}

A system of indicators characterizing the state of financial and economic security and meeting such requirements is presented: are easy to calculate and understand; substantial and meaningful; based on current accounting and statistical reporting; operational for appropriate response to the state of financial security; characterize the qualitative and quantitative state in statics and dynamics.

In the process of conducting scientific and economic research is described as tasksolving. The mechanism of economic security management is revealed. Among the main methods of assessing the system of financial and economic security the following are determined: peer review, regression and analysis of variance, regression method and the method of exponential smoothing methods fuzzy systems, cluster and discriminant analysis. Systematization of methodological approaches to the organization of scientific research in the system of financial and economic security has shown that they are defined in terms of resource (investment) system, infrastructure (cluster) and process approaches. 


\section{References}

Akimova, N., Toporkova, O. and Yevlash, T. (2017), “Accounting and analytical providing of the enterprises' economic security", Economic strategy and perspectives of development of trade and services sphere, no. $1(25)$, pp. 37-50.

Babina, N. (2004), "Management of economic security of the enterprise in the conditions of crisis development”, Ekonomika i upravlinnia, no. 1, pp. 81-85.

Irtyshcheva, I. O. and Kramarenko, I. S. (2011), "Methodical approaches to assessing the creditworthiness of agri-food enterprises", Agrosvit, no. 19, pp. 2-4.

Khomiv, O. (2015), "Features of leadthrough scientifically economic researches", Efektyvna ekonomika, [Online], no. 5, available at: http://www.economy.nayka.com.ua/?op=1\&z=4048 (Accessed 20 September 2020)

Kolisnichenko, P. (2017), "Scientific and methodological approaches to assessing the level of economic security of the enterprise", Investments: practice and access, no. 16, pp. 38-44.

Kramarenko, I. and Kozachenko, L. (2018), "Methods of assessing the creditworthiness of the borrower: A practical aspect”, Economy of Ukraine, no. 5, pp. 49-61.

Ogarok, L. L. (2005), "System approach to economic security management as an integral part of state mechanism on a regional level", Derzhavne upravlinnia: teoriia i praktyka, [Online], no. 2, available at: http://academy.gov.ua/ej/ej2/txts/soc/05ollsdm.pdf (Accessed 20 September 2020)

Putsenteilo, P. and Gumenyuk, O. (2017), “The main aspects of forming an effective system of economic security of the enterprise", The Economic discourse, no. 2, pp. 37-47.

Varicheva, R. (2016), "Methodical approaches to assessing the quality of economic security of the enterprise: accounting support", Khmelnytskyi National University Bulletin, no. 3. no 1, pp. 88-93.

Verhun, A. M. and Strizhko, K. V. (2015), "Modern approaches to assess the level of the company financial security", Efektyvna ekonomika, [Online], no.6, available at: http://www.economy.nayka.com.ua/?op=1\&z=4142 (Accessed 20 September 2020)

Zachosova, N. (2016), "Theoretical and methodological principles of building a system of economic security of financial institutions", Khmelnytsky National University Bulletin, no. 1, pp. 45-55.

Zhurba, I. O. (2018), "The essence of economic security of enterprises in the region", Proceedings of Scientific Works of Cherkasy State Technological University Series Economic Sciences, vol. 48, pp. 124-130, doi: https://doi.org/10.24025/2306-4420.0.48.2018.127362



Цей твір ліцензовано на умовах Ліцензії Creative Commons «/з Зазначенням Авторства - Некомериійна 4.0 Міжнародна» (CC BY-NC 4.0).

This is an open access journal and all published articles are licensed under a Creative Commons "Attribution-NonCommercial 4.0 International" (CC BY-NC 4.0). 